\title{
Effect of Bank Specific And Macroeconomic Determinants on Capital Adequacy Ratio A Study on Ethiopian Private Commercial Banks
}

\author{
ADDISALEM TADESSE BOGALE \\ Department of Business administration and information system, College of Business and Economics, Ambo \\ University, Woliso Campus
}

\begin{abstract}
Capital adequacy implies the conventional assessment of the minimal level of capital, according to certain parameters, which reflect the dimension of banking activity and of related risks, capable to provide a correlation between the supposed obtained benefits and potential loss caused by a certain risk level. Since Capital adequacy ratio (CAR) is the ratio that is set by the regulatory authority in the banking sector, and this ratio can be used to test the health of the banking system. Thus, this study examines the effect of bank specific (Bank Size ,Deposit to Asset Ratio, Loan to Asset Ratio, Loan to Deposit Ratio, Return on Asset, Return on Equity ,Loan Loss Provision) and macroeconomic determinants (Gross Domestic Product and Inflation) on capital adequacy ratio of Ethiopian Private Commercial Banks. In order to investigate these issues a quantitative method research approach is utilized, by using documentary analysis. More specifically, the study uses five years $(2016-2020)$ data for fourteen private commercial banks in Ethiopia. The study used multiple linear regression models to determine the relative importance of each independent variable using OLS to estimate the relationship between CAR its determinants by STATA 13 econometric software. The findings show that bank size, return on equity, loan to asset ratio affect capital adequacy ratio negatively whereas return on asset, loan loss provision affect capital adequacy ratio positively. Hence, it is recommended that to be sure that to be sure that bank have adequate adequacy reserve ,commercial bank and national bank of Ethiopia should give attention to the risk associated with bank size ,caring bank loan and deposit initiating to increase their return on their return on their asset and to manage their equity return.
\end{abstract}

Keywords: Capital adequacy ratio, Ethiopian Private Commercial Banks, Panel data analysis

DOI: $10.7176 / \mathrm{RJFA} / 11-21-01$

Publication date: November $30^{\text {th }} 2020$

\section{I.INTRODUCTION}

Capital adequacy as a concept has been in existence prior to the era of capital regulation in the bankingindustry and there exist several literatures on the determination of capital adequacy ratio (CAR) as well as its determinants. The concept appeared in the middle of the 1970 the expansion of lending activities in banks without any parallel increase in its capital, since capital ratio was measured by total capital divided by total assets (Al-Sabbagh, 2004). This led to the evolution of international debt crisis and the failure of one of the biggest American banks, Franklin National Bank (Koehn and Santomero, 1980). These events forced regulatory authorities to stress more control procedures and to improve new criteria and methods to avoid bank insolvency (Al-Sabbagh, 2004). In an effort to promote efficiency in the banking industry, to control weaknesses resulting from worldwide liberalization and deregulation, the Basel Capital Accord of 1988 (Basel I) which led to the endorsement of a new capital adequacy framework (Basel II) in 2004 (operational from 2007) marked the beginning of a new phase of re- regulation with an attempt to bring about an international harmonization of banking regulations (Bichsel and Blum, 2005).

The Basle Committee on Banking supervision (BCBS) have authority to strengthen regulation and improve the quality of banking supervision worldwide (Bank for International Settlement). The committee publish Basle Capital Accord, it decide to define minimum capital adequacy ratio in the amount of $8 \%$ of risk weighted assets is standardize international banks (Nuviyanti and Anggono, 2014).Using minimum capital adequacy ratios causes promotion instability and inefficiency of the financial system by decreasing the likelihood of insolvency in banks. In the aftermath of the 2007 financial crisis, there have been efforts by regulatory authorities to make banks stronger. To accomplish this, governments across the developed world are enforcing to strengthen their balance sheets by increasing capital, and if they cannot raise more capital, they are told to decrease the amount of risk assets (loans) on their books (Abba, 2013). Capital adequacy generally affects all entities. But as a term, it is most often used in discussing the position of firms in the financial section of the economy, and precisely, whether firms have sufficient capital to cover the risks that they confront (Abba, 2013). Therefore regulatory authorities used capital adequacy ratio as a significant indicator of banks and depository institutions because they view capital as a guard or cushion for absorbing losses.

The National Bank of Ethiopia (NBE), as a central bank, control over the banking sector through issuance of directives pertaining formation and operation of a banking business. NBE has articulated in its Banks Directives 
No. SBB/50/2011 sub article 4 mentioned that all licensed banks shall at a minimum maintain capital to risk weighted assets ratio of $8 \%$ at all times. Thus, given the unique features of banking sector and environment in which they operate and also rapid expansion of banking institutions in Ethiopia, this study seeks to providing full information about the bank specific and macroeconomic determinants of CAR of private commercial banks in Ethiopia by examining the untouched one, and replicating the existing in the Ethiopian context by using 14 private commercial banks operating in the country from 2016 to 2020.

\section{Statement of the problem}

For instance, Williams (2011) studied the impact of macroeconomic variables on the CAR; he noted that macroeconomic variables such as inflation, real exchange rate, money supply, political instability, and Return on investment are significant determinants of regulatory capital., while Baltagi (2005) tested the impact of inflation on the capitalization of Swedish banks and demonstrated that inflation and the banks regulatory capital ratios were inversely related. Buyuk. et.al (2011) concluded that leverage have a negative effect on capital adequacy ratio while Ahmed et al. (2009) concluded that leverage do have a positive impact on bank capital. Al-Sabbagh (2004) stated in his study deposits positively affected to CAR while Bokhari and Ali (2009) share of deposits is strongly negatively affected to CAR. However, the results of those studies were inconsistent. This inconsistency of results might be attributable to the method of data analysis used by different researchers and difference in the economic condition of the countries in which banking sectors are operating.

In addition to the above facts, there has not been much research which is conducted to date on the determinants of capital adequacy ratios of commercial banks in Ethiopia except the study made by Bahiru (2014), and Yonas (2015) studied the determinants of capital adequacy ratio of commercial banks in Ethiopia but considering only bank specific factors. However, other than bank specific variables macroeconomic variables are also very important determinant factors which affect CAR (Dawit, 2015). Moreover, Dawit (2015) analyzed the determinants of capital adequacy ratio of commercial banks in Ethiopia. In those studies, both bank specific and macroeconomic variables were included but the study used only early established banks (senior banks) in the estimation (Banks established before 2005) and some bank specific variable is also missed such as loan to deposit ratio though it is very important determinants of CAR ( Bateni, et al., 2014).

There are eight banks established after 2008 as of the report from NBE, 2016. The inclusion of lately established banks in the estimation is very important to understand the challenges that infant and less experienced banks are facing in the banking industry. Besides, there are inconsistent results in literature regarding the effect of some variables on CAR, for example, Yonas (2015) and Ali etal.(2006) found a negative relationship between ROE and CAR while Meyers et.al(2006)) found a positive relationship between ROE and CAR.

In light of the above facts and the research gaps, the aim of this study is to examine bank specific and macroeconomic determinants of Capital Adequacy Ratio of Private commercial banks in Ethiopia. To this end, this study tried to provide real information about the determinant factors affecting CAR of private commercial banks.

\section{III.Objective of the study}

The general objective of this study is to examine the effect of bank specific and macroeconomic determinants on capital adequacy ratio of Ethiopian Private Commercial Banks. In line with the general objective highlighted above, the following specific objectives are developed.

- To examine the relationship between bank specific determinants (Bank Size, Deposit to Asset Ratio, Loan to asset Ratio, Loan to deposit ratio, Loan loss provision, Return on asset, Return on equity) and capital adequacy ratio,

- $\quad$ To examine the relationship between macroeconomic determinants (Real gross domestic product growth rate and Inflation Rate) and capital adequacy ratio,

- To identify the bank specific determinants which are significantly affecting capital adequacy ratio,

- To identify the macroeconomic determinants which are significantly affecting capital adequacy ratio,

\section{Hypothesis of the study}

In line with the broad purpose statement the following hypotheses are formulated for investigation. Hypotheses of the study stands on the theories related to a bank's capital adequacy ratio that has been developed over the years by banking area researcher's and past empirical studies related to a bank's capital adequacy ratio. This paper examined and tests whether the following nine variables are not significantly affect Capital Adequacy Ratio or not. These hypotheses include:

Ho 1: Bank Size negatively affects CAR.

Ho 2: Deposit to Asset Ratio negatively affects CAR.

Ho3: Loan to asset ratio negatively affects CAR.

Ho 4: Loan to deposit ratio positively affects CAR. 
Ho 5: Loan loss provision negatively affects CAR

Ho 6: Return on asset positively affects CAR.

$\mathrm{H}$ o7: Return on equity positively affects CAR.

Ho 8: Real gross domestic product growth rate negatively affects CAR.

Ho 9: Inflation Rate negatively affects CAR.

\section{LITERATURE REVIEW}

There are numerous studies which dealt with determinants of capital adequacy ratio of banking sector. Some studies were carried out focusing on a single country, while others on a panel of countries. To make this current research project more meaningful some references of previous studies from both panel countries and single countries are presented here.

\section{Panel studies}

Miliaet al., (2014) examined the factors influencing the capital adequacy ratio (CAR) of foreign banks' subsidiaries. They use data from 340 subsidiaries of 123 multinational banks and test whether the subsidiaries' capital ratio depends on the parent banks' fundamentals. They also study the role of the economic conditions and regulatory environment in the bank's home country while determining the CAR of its foreign subsidiaries. Their results provide strong evidence that the CAR of subsidiaries operating in developing and developed countries do not depend on the same set of explanatory factors. They also find that the regulatory framework of a parent bank's home country affects the capitalization of its foreign subsidiaries in the host countries. Finally, they show that specific variables of the parent bank have a stronger effect on foreign banks that are closely related to the interbank market.

RafetAktaset al., (2015) examined the impact of bank-dimensional and environmental factors on bank's capital adequacy ratio in South Eastern European (SEE) region. Size, profitability (ROA), leverage, liquidity, net interest margin (NIM), and risk are used as bank-dimensional explanatory variables in a feasible GLS regression model. On the other hand, economic growth rate, inflation, real interest rate, Eurozone stock market volatility index, deposit insurance coverage, and governance indicator are added to the original model to control for environmental factors. Annual data from 71 commercial banks which belong to 10 different countries in SEE region for the period of $2007-2012$ is used. This region mainly consists of the "transition economies" which are still experiencing the difficulties of turning into efficient market economies with high economic potentials. The results of our study show that among the bank dimensional explanatory variables size, ROA, leverage, liquidity, net interest margin and risk have statistically significant effects in determining CAR for the banks in the region. Among the environmental factors, economic growth rate, Euro zone stock market volatility index, deposit insurance coverage, and governance have statistically significant effects in determining CAR for the banks in the SEE region.

Alkadamani (2015) conducted a research paper on Capital Adequacy, Bank Behavior and Crisis: Evidence from Emergent Economies. Using a simultaneous equations model, this paper examined the impact of capital requirements on bank risk-taking during the recent financial crisis. It also explores the relationship between capital and risk decisions and the impact of economic instability on this relationship. By analyzing the data of 46 commercial banks between 2004 and 2014 from four Middle East countries, the study concludes a positive effect of regulatory pressure on bank capital and bank risk taking. The findings reveal also that banks close to the minimum regulatory capital requirements improve their capital adequacy by increasing their capital and decreasing their risk taking. Furthermore, the results show that economic crisis positively affects bank risk changes, suggesting that banks react to the impact of uncertainty by increasing their risk taking. Finally, the estimations show a positive correlation between banks profitability and increase in capital, indicating that profitable banks can more easily improve their capitalization through retained earnings rather than issuing new securities.

\section{Cross sectional studies}

Buyukşalvarc et.al (2011) examined the determinants of capital adequacy ratio (CAR) in Turkish banks using data from $2006-2011$ for 120 observations. The capital adequacy ratio was used as a dependent variable while indicators that measure: banks size, deposits, loans, loan loss reserves, liquidity, profitability, net interest margin and leverage were used as independent variables. According to the regression results of this study, loans, loans loss reserves, leverage, ROA and ROE have a significant relationship with CAR while bank size, deposits, liquidity and net interest margin do not have effect on CAR in the Turkish banks.

Binh .et.al (2015) examined the relationship between degree of capital adequacy, risks and profitability indicators of Vietnamese commercial banks through both theoretical and empirical studies. They use secondary data from 11 Vietnamese commercial banks during for 6 years (from 2008 to 2013). The data were mainly collected from officially published documents by Vietnamese reputational organizations. Most variables including capital adequacy ratio, risk ratios and profitability ratio during 2008 to 2012 were computed from banks' annual reports. While Capital Adequacy Ratio (CAR) was used as a dependent variable capital risk (CPR), credit risk (CR), interest rate risk (IR), liquidity risk (LR), owner's equity risky assets ratio (ER), asset turnover ratio (ATO), return 
on equity (ROE) and return on assets (ROA)were used as independent variables. The study employed the regression on dependent variables based on three ways: Pooled Regression, Fixed Effect Model, and Random Effect Model. The paper revealed that the adequate capital (CAR) has positive relationship with capital risk (CPR), owner's equity risky assets ratio (ER), asset turnover (ATO), and return on assets (ROA). In contrast, the capital adequacy level is inversely related to credit risk (CR), interest rate risks (IR), liquidity risk (LR), and return on equity (ROE). Al-Tamimi and Obeidat (2013) examined the most important factors that determine the Capital Adequacy of Commercial Banks of Jordan in Amman Stock Exchange for the period from 2000- 2008 using Multiple Linear Regression Analysis and the Correlation Coefficient (Pearson Correlation). The dependent variable was capital adequacy and the independent variables were liquidity risks, credit risks, capital risks, interest rate risk, return on equity, return on assets, revenue power ratio. The result of the study showed the following: There is a statistically significant positive correlation between the degree of capital adequacy in commercial banks and the following independent factors: liquidity risk, and the rate of return on assets. In another hand, there is an inverse relationship with statistical significance between the degree of capital adequacy of commercial banks and factors independent of the rate of return on equity and interest rate risk.

Bokhari and Ali (2009) examined the determinants of capital adequacy ratio in the banking sector of Pakistan. Empirical analyses were conducted by applying statistical tools such as weighted average least square on the panel data from banking sector of Pakistan. Analyses were conducted based on the study of financial statements of 12 sample banks from banking sector of Pakistan; bank-level annual data were used for the period 2005-2009. The dependent variable is capital adequacy ratio while the independent variables are GDP growth rate, share of deposits, average capital adequacy ratio of the sector, portfolio risk and return on risk. The results had revealed that average capital ratio, capital ratio requirement, and portfolio risk level shows weak correlation while share of deposits and return on equity are strongly but negatively correlated with Capital Adequacy Ratio.

Bateniet al., (2014) examined the influential factors of Iranian banks' capital adequacy ratio. They used data collected from annual reports of the sample banks. The data were directly taken from the private banks' balance sheet statement, profit and loss statement and from notes to account. The study period is seven years from 2006 to 2012. The study focused on private banks in Iran which have access to their financial statements. After this selection, our final sample includes 6 banks. Panel data methodology is used in this study to analyze the relationships between bank specific variables [bank size (SIZE), Loan Asset Ratio (LAR), Return on Equity (ROE), Deposit Asset Ratio (DAR), Risk Asset Ratio (RAR), Return on Asset (ROA), Equity Ratio (EQR) and a dependent variable which is capital adequacy ratio (CAR)]. The results indicated negative relationship between bank size and capital adequacy ratio of banks and positive relationship between Loan Asset Ratio (LAR), Return on Equity (ROE), and Return on Asset (ROA), Equity Ratio (EQR), and Capital Adequacy Ratio (CAR). RAR and DAR do not have any impact on capital adequacy ratio.

Nuviyanti and Anggono (2014) examined the determinants of capital adequacy ratio based on risk based bank rating 19 commercial banks in Indonesia. The research involved the use of Multiple Linear Regression based on Ordinary Least Square estimation technique to determine the effect of the independent variables; Good Corporate Governance measured by operating expense to operating income ratio and net interest margin, Risk Profile measured by nonperforming loan ratio and loan to deposit ratio, Earning measured by return on asset ratio and return on equity. Secondary data were obtained from condensed financial statements conventional bank quarterly that derived from Bank of Indonesia covering 2008 to 2013.Using significant level of 5\%, the result is obtained from correlation coefficient, $\mathrm{T}$ test and $\mathrm{F}$ test. The research found that operating expense to operating income ratio, loan to deposit ratio and return on equity ratio have negative significant effect with capital adequacy ratio. On the other hand, non-performing loan ratio and return on asset ratio have positive influence on capital adequacy ratio.

Abba et al., (2013) are examined the relationship between capital adequacy and banking risks. Three independent variables were used. These variables are risk-weighted asset ratio, deposit ratio and inflation rate. Twelve banks were sampled from the population of twenty-two banks in the Nigerian banking industry as of December, 2013. Secondary data were collected from the financial statements of the banks for a period of five years, from 2007 to 2011 . Value at risk theory was adopted to estimate capital adequacy ratio of the banks. Changes in capital adequacy ratio are explained by changes in the independent variables, up to $35 \%$. It was therefore, observed that there is a significant negative relationship between risk and capital adequacy ratio of banks, which means when risk level rises, capital adequacy ratio falls in the Nigerian banking industry. In line with these findings, the study recommended that Nigerian banks should adopt a risk-based approach in managing capital instead of the present practice of focusing on the paid up capital and retained earnings as there is significant relationship between capital adequacy ratio and banking risks. Since the research also provided evidence of negative relationship between deposits and capital adequacy ratio, they also recommended that Nigerian banks should adopt pragmatic approaches to guarantee the safety of depositors money since increase in deposits does not necessarily result to increase in capital adequacy ratio.

Williams (2011) examined the relationship between capital base and some macroeconomic, financial structure and banking variables using an error correction model during $1980-2008$ in Nigeria. As dependent 
variable the author used capital adequacy base while as independent variables: total loans, money supply, interest rate, inflation rate, demand deposit, political instability, exchange rate, liquidity risk, openness of the economy and investments were used. The author concluded that the money supply is a very important determinant of the CAR. The real interest rate is negatively related to capital adequacy base meaning that an increase of real interest rate dampen the capital adequacy base. The real exchange rate is a significant determinant but its coefficient is not as expected while the deposit liabilities and liquidity risk are not statistically significant. The author found out that investments and political instability are correctly signed and statistically significant to explain the capital adequacy base in Nigeria.

\section{Empirical studies in Ethiopia}

Dawit (2015) examined bank specific and macroeconomic determinant factors of Capital Adequacy Ratios of commercial banks in Ethiopia. To this end, the researcher collected secondary sources of panel data over the period 2002-2013 from eight senior commercial banks in Ethiopia selected based on purposive sampling. The research finding revealed that Bank size (BAS), liquidity (LQR) and Non-Performing Loan (NPL) ratio had positive whereas Inflation (INF) had negative, but insignificant effect on CAR of commercial banks in Ethiopia. The share of deposit (DAR), Loan(LAR), Loan provision (LPR), Bank risk (RAR), Return on equity and Economic growth (GDP) had negative and statistically significant effect on Capital Adequacy ratios of commercial banks in Ethiopia. Furthermore, Return on Asset (ROA) and Net Interest Margin (NIM) had positive and statistically significant effect on CAR of commercial banks in Ethiopia. The finding of this study is significant as it revealed to bank managers the relevant factors to take into consideration when they make financial policies to maintain at least the expected required level of CAR. Based on the findings, the study recommended to the management of National Bank of Ethiopia to revise the existing minimum requirement based on Basel III accord and also to influence commercial banks in order to disclose all component of CAR in detail in their annual financial statement.

\section{Conceptual frame work}

The main objective of this study is to examine the determinants of CAR of private commercial banks in Ethiopia. Based on the objective of the study, the following conceptual model is framed. As previously discussed in the related literature review parts, Capital Adequacy Ratio (CAR) is affected by both bank specific and macroeconomic factors. Bank specific factors Bank size (SIZE), DAR (Deposit to Asset Ratio), Loan to Asset Ratio (LAR), Loan to Deposit (LTD), Return on Asset (ROA), Return on Equity (ROE), Loan Loss Provision (LPR) whereas macroeconomic factors are-Real Gross Domestic Products (GDP) and inflation rate (INF). Thus, the following conceptual model is framed to summarize the main focus and scope of this study in terms of variables included. The Green color part represents the dependent variables used in this study.

Bank specific factor
SIZE
DAR,
LAR
LTD
ROA
ROE
LPR
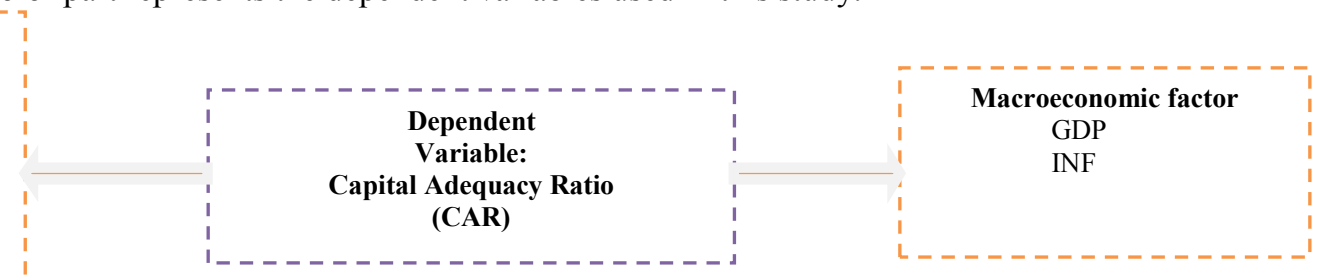

Figure 2.1 Conceptual Framework

Source: Dawit (2015) with modification on variable lists

\section{VI.RESEARCH METHODOLOGY}

\section{Research design and approaches}

Research designs are plans and the procedures for research that span the decisions from broad assumptions to detailed methods of data collection and analysis. The researcher intention was to investigate the determinant of capital adequacy ratio in Ethiopian commercial banks to achieve the objective of this study, Explanatory research design was adopted. Explanatory research design examines the cause and effect relationships between dependent and independent variables Kothari (2004). Therefore, this study was examined the cause and effect relationships between Capital Adequacy ratio and its determinants, it is an explanatory research.

The objective to be achieved in the study is a base for determining the research approach for the study. As noted in Creswell (2003) in terms of investigative study there are three familiar types of research approaches to business and social research namely, quantitative, qualitative and mixed methods approach. Therefore, the following discussion briefly presents the basic nature of quantitative approaches that this study is mainly focused on. Quantitative research is a means for testing objective theories by examining the relationship among variables (Creswell, 2003). Further quantitative research approach has the advantage of being able to make generalizations, for a broader population, based on findings from the sample. In case, if the problem identified is factors affecting the outcome having numeric value, it is quantitative approach (Creswell, 2003). Therefore, the researcher employed quantitative research approach to analyze the relationship between the bank related and macro-economic factors and Capital Adequacy ratios of the various private banks in Ethiopia. Thus, the research was used a panel 
data from 2016 to 2020 .

\section{Population and sampling procedure}

This study seeks to analyze both internal and external factors that affect the Capital adequacy Ratio of Ethiopian private commercial banks. Thus for the study populations are all private Commercial banks in Ethiopia. According to NBE (2016/17), reports there are Seventeen Commercial Banks. Out of the Seventeen Commercial Banks, Commercial Bank of Ethiopia (CBE) is state owned bank whereas the remaining are private Banks such as; Awash International Bank S.C (AIB), DashenBank S.C (DB), Wogagen Bank S.C (WB), United Bank S.C (UB), Nib International Bank S.C (NIB), Bank of Abyssinia S.C (BOA), Lion International Bank S.C (LIB), Cooperative Bank of Oromia S.C (CBO), Berehan International Bank S.C (BIB), Buna International Bank S.C (BUIB), Oromia International Bank S.C (OIB), Zemen Bank S.C (ZB), Addis InternationalBank S.C ( AIB), Abay Bank S.C (AB), Enat Bank S.C (EB) and Debub Global Bank S.C (DGB). Among the non-probability, sampling techniques purposive sampling was used to select samples from the total population. Non-probability sampling technique is selected because random sampling is not appropriate for the study. The total population is sixteen but for the study purpose, the sample size is fourteen. Out of those fourteen banks almost half of them started their operation on average around 2010 (NBE report, 2017). Hence, to include the newly established banks and considering having at least a five years panel data which is worthwhile for panel data estimation (Green, 1998), the study selects those banks which are operating since 2010 onward. Since the study covers a period of 5 years, there are banks with the age of less than 5 years that is why purposive sampling is used. The study includes all Private Commercial Banks, with 5 and above establishment year. The sample size is fourteen, which includes, Awash International Bank S.C (AIB), Dashen Bank S.C (DB), Wogagen Bank S.C (WB), United Bank S.C (UB), Nib International Bank S.C (NIB), Bank of Abyssinia S.C (BOA), Lion International Bank S.C (LIB), Cooperative Bank of Oromia S.C (CBO), Berehan International Bank S.C (BIB), Buna International Bank S.C (BUIB), OromiaInternational Bank S.C (OIB), Zemen Bank S.C (ZB),Abay Bank S.C (AB) and Addis International Bank Sc(ADIB).The researcher believes that the sample size is sufficient to make sound conclusion about the population as far as it covers around $82 \%$ of the total population. Therefore, the matrix for the frame is $14 * 5$ that includes 70 observations.

Data Analysis

The objective of this study is to examine the determinants of Capital Adequacy Ratios of Private Commercial Banks in Ethiopia. To achieve this objective the study used panel data which was collected through structured document review. Thus, the collected panel data was analyzes using descriptive statistics, correlations and multiple linear regression analysis. Mean values and standard deviations was used to analyze the general trends of the data from 2016 to 2020 based on the sector sample of 14 banks and a correlation matrix was also use to examine the relationship between the dependent variable and explanatory variables. A multiple linear regression model was used to determine the relative importance of each independent variable in influencing CAR. For this study, the regression analysis known as OLS will use to estimate the relationship between CAR and its determinants. The multiple linear regressions model was run, and thus OLS conduct using STATA 13 econometric software package, to test the casual relationship between the CAR and its determinant and to determine the most significant and influential explanatory variables affecting the CAR of Private Commercial Banks in Ethiopian. Moreover, the diagnostic tests was undertaken in order to check the validity of the model and fulfill the assumption of the Classical Linear Regression Model. Accordingly, before applying the model for testing the significance of the slopes and analyzing the regressed result, normality, multicolinearity, autocorrelation and heteroscedasticity tests are made for identifying misspecification of data if any so as to fulfill research quality.

\section{Model specification}

In this study, panel data was used. As noted in Brooks (2008), a panel keeps the same individuals or objects and measures some quantity about them overtime. A panel data could be analyzed using pooled OLS model, fixed effect model or Random effect model (Brooks, 208). The following multivariate ordinary least square (OLS) regression model is specified and used to see the extent relationship between the Capital adequacy ratio (CAR) and its determinants in the selected private commercial banks as adopted from Brooks (2008):

$$
\mathbf{Y}_{\mathrm{it}}=\boldsymbol{\beta} \mathbf{0}+\boldsymbol{\beta} \mathbf{X}_{\mathrm{it}}+\boldsymbol{\varepsilon}_{\mathrm{it}}
$$

Where: - $\mathbf{Y}_{\text {it }}$ is the dependent variable for firm ' $\mathbf{i}$ ' in year ' $\mathbf{t}$ ', $\boldsymbol{\beta} \mathbf{o}$ is the constant term, $\boldsymbol{\beta}$ is the coefficient of the independent variables of the study, Xit is the independent variable for firm ' $\mathbf{i}$ ' in year ' $\mathbf{t}$ ' and cit the normal error term.

The estimated models used in this study are presented as follow;

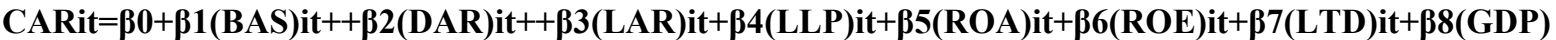 it $+\beta 9($ INF $)$ it + eit}

Where:

$>\beta 0$ is an intercept,

$>\quad \beta 1, \beta 2, \beta 3, \beta 4, \beta 5, \beta 6, \beta 7, \beta 8, \beta 9$, represent estimated coefficient for specific bank $\mathrm{i}$ at time $\mathrm{t}$,

$>\mathrm{CAR}_{\mathrm{it}}$ : The capital adequacy ratio for bank $\mathrm{i}$ at time $\mathrm{t}$,

$>$ BAS $_{\text {it: }}$ Total assets for bank $\mathrm{i}$ at time $\mathrm{t}$, 
$>\mathrm{DAR}_{\mathrm{it}}$ : The ratio of total deposit to total assets for bank $\mathrm{i}$ at time $\mathrm{t}$,

$>\mathrm{LAR}_{\mathrm{it}}$ : The ratio of total loans to total assets for bank $\mathrm{i}$ at time $\mathrm{t}$,

$>$ LLP $_{\text {it: }}$ loan loss provision of bank $\mathrm{i}$ at time $\mathrm{t}$,

$>$ ROA $_{\text {it: }}$ Return on assets for bank $\mathrm{i}$ at time $\mathrm{t}$,

$>\mathrm{ROE}_{\mathrm{it}}$ : Return on equity for bank $\mathrm{i}$ at time $\mathrm{t}$,

$>$ LTD $_{\text {it: }}$ Loan to deposit

$>$ GDP $_{\text {it: }}$ Real GDP growth rate of Ethiopia at time $t$,

$>\mathrm{INF}_{\mathrm{it}}$ : The overall inflation rate in Ethiopia at time $\mathrm{t}$,

$>\mathrm{t}$ : Time,

$>\varepsilon_{\mathrm{it}}:$ the normal error term.

\section{DATA ANALYSIS AND DISCUSSION}

Correlation analysis and diagnostic test

Additionally, Correlation analysis could have three important advantages. First, it tells whether the relationship between the dependent variable is positive or negative. Second, it tells whether the relationship is strong or not. Third, it tells about whether there is multicolinarity problem or not.

\begin{tabular}{|c|c|c|c|c|c|c|c|c|c|c|}
\hline & CAR & BAS & DAR & LAR & LTD & ROA & ROE & LLP & INF & GDP \\
\hline CAR & 1 & & & & & & & & & \\
\hline BAS & -0.1566 & 1 & & & & & & & & \\
\hline DAR & -0.2510 & 0.6215 & 1 & & & & & & & \\
\hline LAR & 0.0694 & 0.5041 & 0.3399 & 1 & & & & & & \\
\hline LTD & 0.2771 & 0.0170 & -0.4289 & 0.6991 & 1 & & & & & \\
\hline ROA & 0.5998 & -0.0169 & -0.1729 & -0.0924 & 0.0456 & 1 & & & & \\
\hline ROE & 0.2839 & 0.4153 & 0.3553 & 0.0540 & -0.2072 & 0.7249 & 1 & & & \\
\hline LLP & 0.0259 & 0.0021 & 0.0895 & -0.2867 & -0.3353 & 0.2529 & 0.2812 & 1 & & \\
\hline INF & -0.0504 & -0.3380 & -0.2507 & -0.3708 & -0.1627 & 0.1402 & 0.1021 & 0.2475 & 1 & \\
\hline GDP & -0.0598 & -0.0661 & 0.0285 & -0.1035 & -0.1110 & 0.1077 & 0.0647 & 0.0714 & -0.3783 & 1 \\
\hline
\end{tabular}

Source: Authors own computation based on banks annual reports data

The correlation table 1 shows that there is a negative correlation between CAR and BAS, DAR, INF and GDP variables, whereas there is a positive relationship between CAR and LAR, LTD, ROA, ROE, and LLP. Besides, the correlation between all variables one another is less than 0.6 on average, which implies that, there is no multicolinarity problem.

Econometrics analysis

This paper is aiming to see the extent relationship between the dependent variable, Capital Adequacy Ratio (CAR) and independent Variables which include Bank size (BAS), DAR (Deposit to Asset Ratio), Loan to Asset Ratio (LAR), Loan to Deposit (LTD), Return on Asset (ROA), Return on Equity (ROE), Loan Loss Provision (LLR), and macroeconomic variables (gross domestic product and inflation). Using a panel data collected from 14 private owned banks for the year 2016 to 2020. The study regress the fixed effect model and the random effect model and checked for the significance of the covariance between the unobserved heterogeneity and the exogenous variable (please see appendix A, and B, for the fixed effect and random effect estimation). 
Hausman specification test

Table 2: Hausman test for fixed effect and random effect

\begin{tabular}{l|llll} 
& $\begin{array}{l}\text { Coefficients } \\
(\mathrm{b})\end{array}$ & $\begin{array}{l}(\mathrm{B}) \\
\text { random }\end{array}$ & $\begin{array}{c}(\mathrm{b}-\mathrm{B}) \\
\text { Difference }\end{array}$ & sqrt (diag(V_b-V_B)) \\
& $\begin{array}{l}.015942 \\
\text { BAS }\end{array}$ & .0009147 & .0150273 & .0117428 \\
DAR & -.1462807 & -.1345984 & -.0116823 & .0496989 \\
LAR & .1373538 & .1123246 & .0250292 & .0122907 \\
LTD & -.0298764 & .0138358 & -.0437122 & .0119919 \\
ROA & 1.994265 & .7719373 & 1.222328 & .27669 \\
ROE & -.1084068 & .0076722 & -.1160789 & .0489067 \\
LLP & .0988691 & .1149607 & -.0160917 & .0263232 \\
INF & .0263092 & -.0206862 & .0469954 & .0386676 \\
GDP & -.0643831 & -.1858748 & .1214916 & .1916917 \\
\hline
\end{tabular}

$\mathrm{b}=$ consistent under Ho and Ha; obtained from xtreg

$\mathrm{B}=$ inconsistent under Ha, efficient under Ho; obtained from xtreg

Test: Ho: difference in coefficients not systematic

$$
\begin{aligned}
& \operatorname{chi} 2(9)=(b-B)^{\prime}\left[\left(V_{-} b-V_{-} B\right)^{\wedge}(-1)\right](b-B) \\
& =5.12 \\
& \text { Prob }>\text { chi } 2=0.8240
\end{aligned}
$$

(V_b-V_B is not positive definite)

\section{Source: Authors own computation based on banks annual reports data}

The Hausman test with a P-Value of 0.82 , we fail to reject the null hypothesis which says fixed effect is not the appropriate model or in another word there is no correlation between the exogenous variable and unobserved heterogeneity variable. Hence random effect model is the appropriate model given that there is an evidence of significant differences across banks. If there is no evidence of significant difference across banks then a Random effect will not be efficient. In the situation where there is no significant difference among banks, a simple OLS model becomes efficient and consistent estimate than the random effect model. To check whether a random effect or a simple OLS model is appropriate the paper conducts Breusch- Pagan Lagrange multiplier (LM) test.

Table 3: Breusch-Pagan Lagrange multiplier (LM) test for random effect

\begin{tabular}{|l|l|l|}
\hline $\mathrm{CAR}[$ Bank, $\mathrm{t}]=\mathrm{Xb}+\mathrm{u}[\mathrm{Bank}]+\mathrm{e}[\mathrm{Bank}, \mathrm{t}]$ \\
\hline Estimated results: & Var & sd = sqrt(Var) \\
\hline CAR & 0.0004453 & 0.021102 \\
\hline $\mathrm{E}$ & 0.0003165 & 0.017789 \\
\hline $\mathrm{U}$ & 0.0000212 & 0.0045996 \\
\hline Test: $\operatorname{Var}(\mathrm{u})=0$ & \\
\hline chibar2(01 $=0.15$ & \\
\hline Prob $>$ chibar2 $=0.3514$ &
\end{tabular}

\section{Source: Authors own computation based on banks annual reports data}

The test result of LM with a P-Value of 35.14, we can't reject the null hypothesis which says random effect is the correct model and this implies that there is no evidence of significant differences across banks; therefore, we can run a simple OLS regression. Before OLS regression the study has cheeked weather error terms are normally distributed or not using skewness and kurtosis as presented in table 3.

OLS regression

As explained in the previous section OLS estimator will be used to estimate the model specified in equation and the diagnostic tests. 
Table 4: OLS regression

\begin{tabular}{|c|c|c|c|}
\hline Indep variables & Coefficient & $t$ & $P>/ t /$ \\
\hline BAS & -.0059 & -2.05 & $0.045 * *$ \\
\hline DAR & .7074 & 2.91 & $0.005 * *$ \\
\hline LAR & -1.027 & -2.75 & $0.008 * *$ \\
\hline LTD & .8098 & 3.00 & $0.004 * *$ \\
\hline $\mathrm{ROA}$ & 1.875 & 5.42 & $0.000 * * *$ \\
\hline ROE & -.0559 & -1.21 & 0.232 \\
\hline LLP & .0637 & 0.80 & 0.427 \\
\hline INF & -.0559 & -2.48 & $0.016 * *$ \\
\hline GDP & -.6440 & -2.75 & $0.008 * *$ \\
\hline Constant & -.3745 & -2.13 & $0.038 * *$ \\
\hline \multicolumn{2}{|c|}{ Number of observations $=70$} & \multicolumn{2}{|c|}{ R-Squared $=0.5789$} \\
\hline \multicolumn{2}{|c|}{ Number of groups $=14$} & \multicolumn{2}{|c|}{ Adj $R$-squared $=0.5157$} \\
\hline \multicolumn{2}{|l|}{$F(9,60)=9.16$} & \multicolumn{2}{|c|}{ Root MSE $=0.1469$} \\
\hline \multicolumn{2}{|l|}{ Prob $>F=0.0000$} & \multicolumn{2}{|c|}{ Model-OLS Regression } \\
\hline
\end{tabular}

Values in brackets are standard of errors. $* * * 1 \%$ significant level, $* *$ is $5 \%$ significant level and $* 10 \%$ significant level

Source: Authors own computation based on banks annual reports data

As we can see from the above table in the regressions, all independent variables together are significantly affects the dependent variable which is represented by Prob> F which is less than $1 \%$ and concluded that the models is correct. The R2 measure for the model is also higher than $50 \%$ and implies that independent variables have the power to explain the variation occurred in dependent variable. Regarding to individual significant level, there are seven variables (BAS, DAR, LAR, LTD, ROA, INF and GDP) which affect the dependent variable at significance level of $5 \%$ and $1 \%$, and two variables (ROE, LPR) which affect the dependent variable but unexpectedly statistically insignificant.

Unlike previous studies (Bahiru, 2014; Yonas, 2015 and Dawit, 2015), this paper found that, there are many significant variables for the overall bank regression model and the study discusses the findings with the last model.

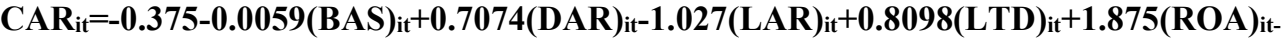

$0.0559(\text { ROE })_{\text {it }}+0.0637(\text { LLP })_{\text {it }} \mathbf{- 0 . 0 5 5 9}$ (INF) $)_{\text {it }}-0.6440(\text { GDP })_{\text {it }}$

Before the discussion part, post estimation tests are presented to be sure that the selected model is consistent and efficient. The study undertakes post estimation tests of model specification, multicoliniarity test and hetroscdasticity test. For an OLS estimates to be BLUE (best linear unbiased estimates) the aforementioned tests should have to be satisfied.

The first test is, model specification test, which checks the existence of measurement error, omitted variable and inclusion of irrelevant variable in our estimates. The test result confirms that there is no problem of model specification with a P-Value of 0.44 , where we fail to reject the null hypothesis which says there is no omitted variable problem (model specification problem).

Table 3: Model specification test

\begin{tabular}{|ll|}
\hline Ramsey RESET test using powers of the fitted value of CAR & Ho: model has no omitted variables \\
\hline $\mathrm{F}(3,65)=0.91$ & Prob $>\mathrm{F}=0.4402$ \\
\hline
\end{tabular}

\section{Source: Authors own computation based on banks annual reports data}

The second post estimation test is multicoliniarity test. This test is conducted to check whether there is serial correlation among independent variables or not using Variance inflation factor (VIF). The result of VIF is 2.65 is lower than the critical value of 10 . Hence, there is no problem of multicolinarity problem. 


$\begin{array}{lll}\begin{array}{l}\text { Table 4: Multicolinearity test } \\ \text { Variable }\end{array} & \text { VIF } & \mathbf{1 / V I F} \\ \text { BAS } & 2.60 & 0.384319 \\ \text { DAR } & 3.01 & 0.332575 \\ \text { LAR } & 2.85 & 0.350931 \\ \text { LTD } & 3.03 & 0.329924 \\ \text { ROA } & 3.28 & 0.304548 \\ \text { ROE } & 4.47 & 0.223881 \\ \text { LLP } & 1.30 & 0.771411 \\ \text { INF } & 1.93 & 0.517232 \\ \text { GDP } & 1.40 & 0.715825 \\ \text { Mean VIF } & 2.65 & \end{array}$

Source: Data obtained from Commercial Banks and Own computation

\section{Conclusion}

This paper conducted different estimation to see the relationship between the dependent variable, Capital Adequacy Ratio (CAR) and independent Variables which include Bank size (BAS), DAR (Deposit to Asset Ratio), Loan to Asset Ratio (LAR), Loan to Deposit (LTD), Return on Asset (ROA), Return on Equity (ROE), Loan Loss Provision (LPP), and macroeconomic variables (gross domestic product and inflation). Fixed effect and random effect models were not accepted after hausman and Breusch-Pagan Lagrange multiplier (LM) tests respectively. The test results showed that there is no significant difference between banks. Hence, this paper used OLS model to determine factors affecting capital adequacy ratio. The paper did all pre and post estimation tests to be sure that the model is appropriate.

The result from the OLS regression result showed that BAS, DAR, LAR, and LTD are significant at five percent of significant level, whereas ROA is significant at one percent of significant level.

\section{REFERENCES}

(1) Abba, Gabriel Ogere., \& Peter, Zachariah. Capital Adequacy Ratio and Banking Risks in the Nigeria Money Deposit Banks.Vol.4, No.17, 2013.

(2) Al-Sabbagh, N.M. (2004). Determinants of Capital Adequacy Ratio in Jordanian Banks.M.Sc. thesis, Yarmouk University, Jordan.

(3) Al-Tamimi, KhaledAbdallaMoh'd.,\&Obeidat, SamerFakhri.,Determinants of Capital Adequacy in Commercial Banks of Jordan an Empirical Study.Vol.2, No.4, July 2013.

(4) Bahiru W., 2014. Determinants of Capital adequacy Ratio of Commercial Banks inEthiopia: Addis Ababa University, Ethiopia. MSc. Thesis.

(5) Baltagi, B. (2005). Econometric Analysis of Panel Data. England: John Wiley \& Sons Ltd, The Atrium, Southern Gate, Chichester, West Sussex PO19 8SQ.

(6) Bateni, L., Vakilifard, H. \&Asghari, F., 2014.The Influential Factors on Capital Adequacy Ratio in Iranian Banks.International Journal of Economics and Finance, 6(11).

(7) Bichsel, R. and Blum, J. (2005).Capital regulation of banks: Where do we stand and where are we going?

(8) Binh, Dao Thanh., Capital Adequacy \& Banking Risk - An Empirical Study on Vietnamese Banks. 12 February 2015.

(9) Bokhari, L. H., Syed, M. A. \&Khurram, S. (2012). Determinants of Capital Adequacy Ratio in Banking Sector: An Empirical Analysis from Pakistan. Academy of ContemporaryResearch Journal, 2(1),1-9.

(10) Brooks, C., 2008. Introductory Econometrics for Finance.2nd ed. New York.

(11) Buyukşalvarc1, Ahmet.,\&Abdioğlu.Hasan., Determinants of Capital Adequacy Ratio in Turkish Banks: A Panel Data Analysis Vol.5(27), pp11199-11209, 9 November 2011.

(12) Creswell,W., 2003. Qualitative, Quantitative, and Mixed Methods Approaches.2nd ed.

(13) Dawit W., 2015. Determinants of Capital Adequacy Ratio: An Empirical Study on Commercial Banks of Ethiopia. Addis Ababa university, Ethiopia .Msc Thesis.

(14) Green,W. H. (2008). Econometric Analysis. New Jersey, Pearson Education Inc.

(15) KhaledAlkadamani, 2015. Capital Adequacy, Bank Behavior and Crisis: Evidence from Emergent Economies. European Journal of Sustainable Development.

(16) Koehn, M., \&Santomero, M. A. (1980).Regulation of Bank Capital and Portfolio Risk.TheJournal of Finance,35(5). http://dx.doi.org/10.1111/j.1540-6261.1980.tb02206.x

(17) Kothari, C., 2004. Research Methodology, Methods and Techniques.2nd ed. India: University Of Rajasthan.

(18) Meyers, LS, Gamut, G and Guarino, AJ 2006 "Applied Multivariate Research: Designand Interpretation, $S A G E$ publications, New Delhi. www.itl.gov/div898/handbook 
(19) Mili, M., Sahut, J. M. \&Trimeche, H. (2014). Determinants of the Capital Adequacy Ratio of a Foreign Bank's Subsidiaries: The Role of the Interbank Market and Regulation of Multinational Banks. Ipag Business School Working Paper Series, 366, 1-17.

(20) NBE 2014/15, "Annual report", National Bank of Ethiopia, Addis Ababa, Ethiopia

(21) NBE, 1995.Computation of Risk weighted Asset Directive No. SBB/9/95, Addis Ababa: National Bank of Ethiopia.

(22) NBE, 2008.Asset Classification and Provisioning Directive No. SBB/43/2008., Addis Ababa: National Bank of Ethiopia.

(23) Nuviyanti and AchmadHerlantoAnggono, 2014.Determinant of capital adequacy ratio (CAR)in 19 commercial Banks in indonesia period year 2008-2013. School of Business and Management Institute Technology Bandung, IndonesiaVol . 3, No .7, 20 14: 75 2-764

(24) Rafet, A., Suleyman, A., Bilge, B. \&Gokhan, C., 2015. The Determinants of Banks' Capital Adequacy Ratio: Some Evidence from South Eastern European Countries. Journal of Economics and Behavioral Studies, February, 7(1), pp. 79-88.

(25) Williams, H. T. (2011). Determinants of Capital Adequacy in the Banking Sub-sector of the Nigerian Economy: Efficacy of CAMELS.(A Model Specification with Co-integration Analysis). International Journal of Academic Research in Business and Social Sciences, 1(3), 234-246.

(26) Yonas M., 2015. Determinants of Capital adequacy Ratio of Commercial Banks in Ethiopia:European Scientific Journal September 2015 edition vol.11, No.25 ISSN: 1857 - 7881(Print) 